\title{
EFFECTS OF THE ELECTROLYTIC TREATMENT ON BACILLUS SUBTILIS
}

\author{
Rodolfo Tolentino-Bisneto*; Ederio D. Bidoia \\ Departamento de Bioquímica e Microbiologia, Instituto de Biociências de Rio Claro, Universidade Estadual Paulista, \\ Rio Claro, SP, Brasil.
}

This paper corresponds to an "extended abstract" selected for oral presentation in the $22^{\text {nd }}$ Brazilian Congress of Microbiology, held in Florianópolis, SC, Brazil, in November 17-20, 2003

\begin{abstract}
Conventional processes of water disinfection can generate toxic composites. It is the case of the trihalomethanes (carcinogenic) formed in the contact of chlorine with organic substances present in the water. The electrolytic treatment can be a substitute for the chlorination process without the need for addition of chemical substances to the process. The effect of the electrolytic treatment using carbon cathode on the viability of the microorganism Bacillus subtilis was tested to determine the death process. By means of electronic microscopy, it was observed that the main cause of the microorganism's death was the cellular lysis due to the electroporation in the cell membrane.
\end{abstract}

Key words: disinfection, electrolytic treatment, electroporation, electronic microscopy.

\section{INTRODUCTION}

The traditional water treatment comprises the addition of chemical substances, which can generate toxic composites that may affect the user's health. The most used treatment method is chlorination, but this method promotes formation of trihalomethanes and chloramines, which are carcinogenic and have other toxicologic effects $(1,5)$. The electrolytic treatment can be an alternative method for disinfection of drinking and waste water.

Death of bacteria during electrolytic treatment has been attributed to several factors, such as: generation of disinfectant compounds like chlorine and ozone (8); charge-transfer in the electrode/bacterium interface $(6,7,8)$; destruction of the cytoplasmatic membrane or simply an increase in its permeability $(2,3,4)$.

This work intends to observe the effect of the electrolytic treatment with carbon cathode on the Bacillus subtilis cell using scanning electronic microscopy.

\section{MATERIALS AND METHODS}

Suspensions of Bacillus subtilis CCT 2576 were electrolyzed by $0.60 \mathrm{~A}$, direct current, at $30 \mathrm{~min}$ in batch system. A carbon vitrified electrode (Tokai Carbon Co. - Japan) was used as cathode and a platinum foil (Aldrich $-99.98 \% \mathrm{~m} / \mathrm{m}$ ) covered with a dialysis membrane was the anode. The dialysis membrane does not permit the disinfection at the anode. Before and after the electrolytic treatment, B. subtilis cells were examined by scanning electronic microscopy (SEM) - Phillips model SE 5008 - and transmission electronic microscopy (TEM) - Phillips CM 100.

\section{RESULTS AND DISCUSSION}

Figs. 1 and 2 show $B$. subtilis before and after the application of the electrolytic treatment, respectively. Before treatment, the B. subtilis cells showed regular morphology, without leakage points (Fig. 1). After treatment, the cells showed lysed material

*Corresponding author. Mailing address: Departamento de Bioquímica e Microbiologia, Instituto de Biociências de Rio Claro, Universidade Estadual Paulista. Av. 24-A, 1515, Bela vista. 13506-900, Rio Claro, SP, Brasil. Tel.: (+5519) 3526-4191. Fax: (+5519) 3526-4176. E-mail: ederio@rc.unesp.br 
(Fig. 2) and reduced average size. Extravasation points in the cell wall were also observed.

Fig. 3 shows a longitudinal cut of a $B$. subtilis cell before the electrolytic treatment. The cell shows nuclear material (Fig. 3) involved by an unbroken cell wall. The cytoplasm occupies all intracellular space, being delimited by the plasmatic membrane. Fig. 4 shows a transversal cut of a $B$. subtilis cell after $30 \mathrm{~min}$ of the electrolysis. The cell wall presents holes and part of the cytoplasm is leaking (Fig. 4). Probably, the cell lysed due to irreversible electroporation $(3,4)$. Beyond electroporation, these alterations can be caused by other effects, like exposition to electric fields and direct charge-transfer in the electrode-solution interface $(5,6,7,8)$.

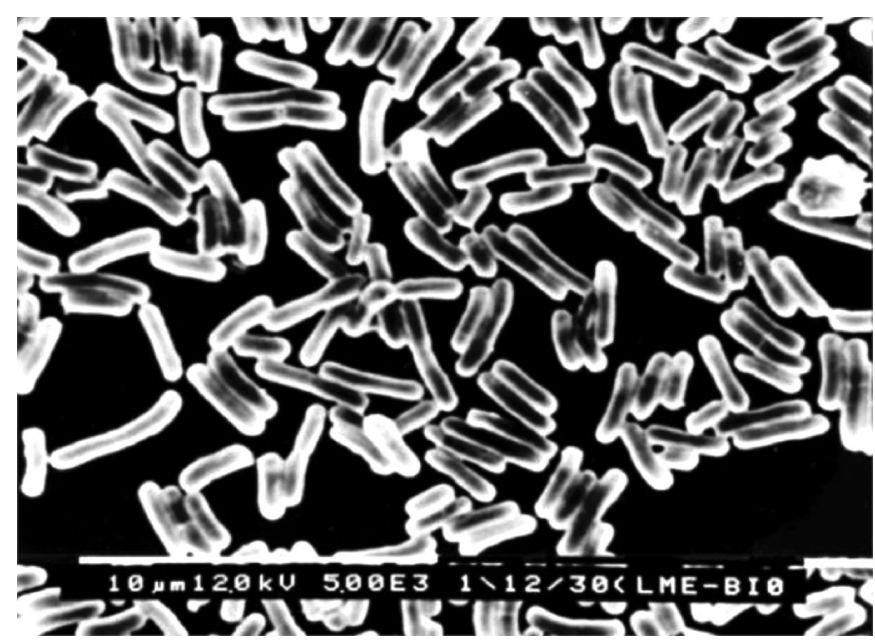

Figure 1. Micrograph of Bacillus subtilis by SEM.

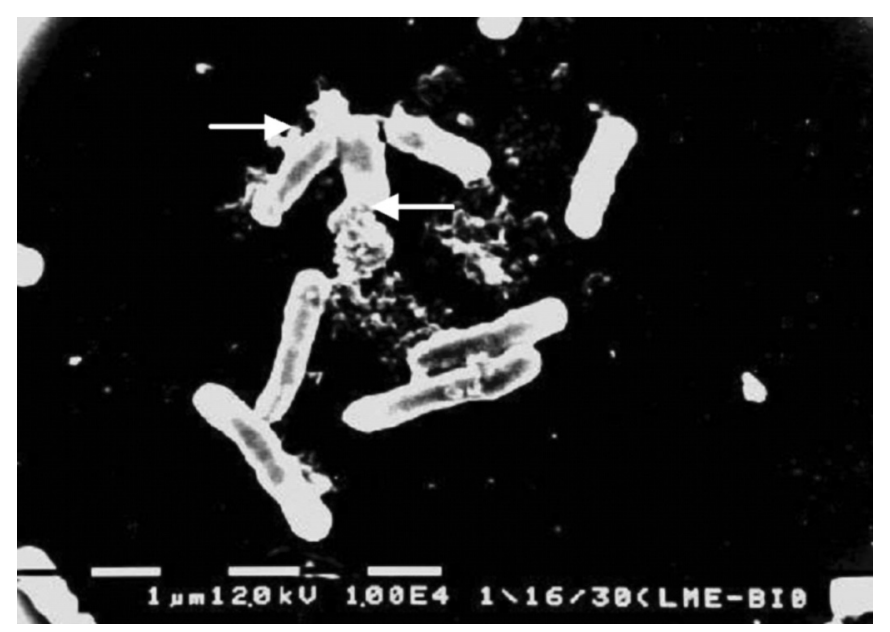

Figure 2. Micrograph of Bacillus subtilis by SEM after $30 \mathrm{~min}$ of electrolytic treatment. Arrows: extravasation points.

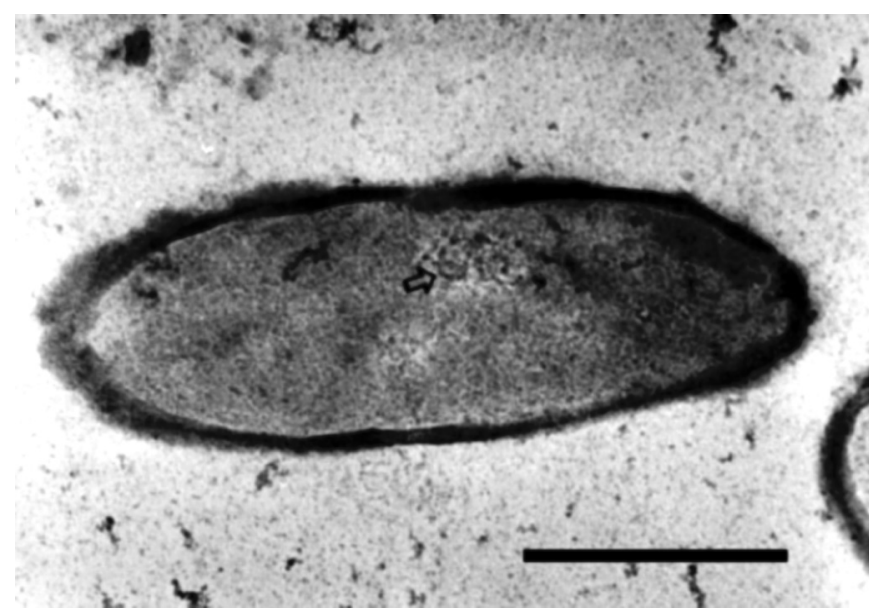

Figure 3. Micrograph by TEM of Bacillus subtilis. Arrows: nucleic material. Scale: $0.5 \mathrm{~mm}$.

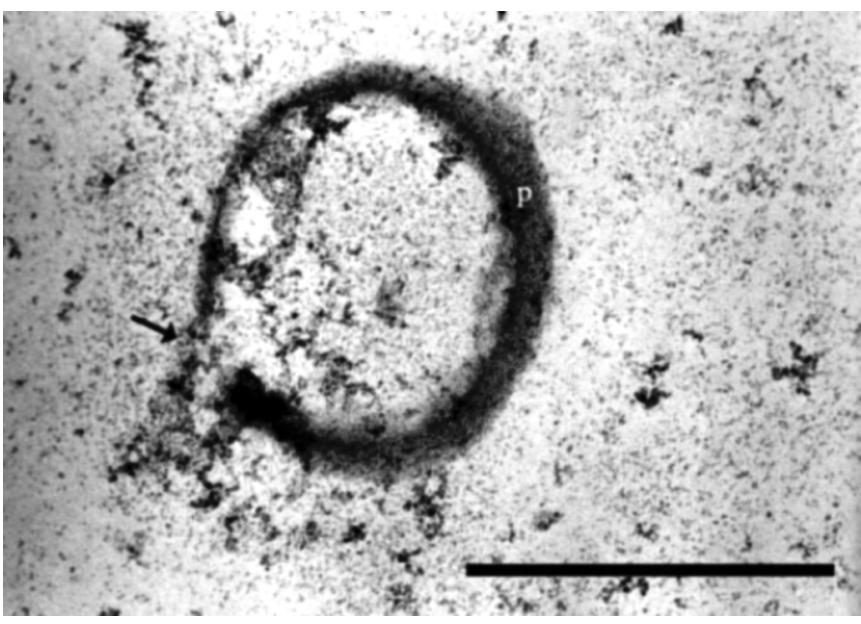

Figure 4. Micrograph by TEM of Bacillus subtilis after $30 \mathrm{~min}$ of electrolytic treatment. Arrows: extravasation point. P: cell wall. Scale: $0.5 \mathrm{~mm}$.

\section{CONCLUSION}

The results allow to conclude that the main cause of $B$. subtilis death was the cellular lysis, caused probably by the irreversible electroporation $(2,3,4)$. The potential applied in the treatment was between 8.7 and $11.9 \mathrm{~V}$ which is enough to provoke this phenomenon (4).

\section{ACKNOWLEDGMENTS}

CAPES, FUNDUNESP and CNPq for financial support. 


\section{RESUMO}

\section{Efeito do tratamento eletrolítico em Bacillus subtis}

Processos convencionais de desinfecção de águas podem gerar compostos tóxicos. Esse é o caso dos trialometanos formados na reação do cloro com compostos orgânicos presentes na água. O tratamento eletrolítico pode ser um substituto à cloração com vantagem de não requer a adição de nenhum composto na água. O efeito do tratamento eletrolítico, utilizando eletrodos de carbono, na viabilidade de Bacillus subtilis foi testado para se determinar o mecanismo de morte. Através de microscopia eletrônica, foi possível evidenciar que a morte do microrganismo se deu pela lise celular, provavelmente provocada pela eletroporação irreversível da membrana celular.

Palavras-chave: desinfecção, tratamento eletrolítico, eletroporação, microscopia eletrônica.

\section{REFERENCES}

1. Condie, L.W. Toxicological effects associated with drinking water disinfectants and their by- products. In: Joley, R.L.; Condie, L.W.; Jonson, J.D.; Katz, S.; Minear, R.A.; Jacobs, V.A. Water Chlorination Chemistry, Environmental Impact and Health Effects v. 6, Lewis Publishers, Boca Raton, p.281-291, 1990.

2. Friendrich, U.; Stachowicz, N.; Simm, A.; Fuhr, G.; Lucas, K.; Zimmermann, U. High Efficiency electrotransferction with aluminum electrodes using microsecond controlled pulses. Bioelectrochem. Bioenerg., 47:103-111, 1998.

3. Lee, S.W.; Tai, Y.C. A micro cell lysis device. Sens. Actuators B. Chem., 73:74-79, 1999.

4. Lubick, P.; Jayaram, S. High voltage pulse application for the destruction of Gram-negative bacterium Yersunia enterocolitica. Bioelectrochem. Bioenerg., 43:135-141, 1997.

5. Matsunaga, T.; Nakasono, S.; Takamuku, T; Burgess, J.G.; Nakamura, N.; Sode, K. Disinfection of drinking water by using a novel electrochemical reactor employing carbon-cloth electrodes. Appl. Environ. Microbiol., 58:686-689, 1992.

6. Nakasono, S.; Burgess, G.; Takahashi, K.; Koike, M.; Murayama, C.; Nakamura, S.; Matsunaga, T. Electrochemical prevention of marine biofouling with a carbom-chloroprene sheet. Appl. Environ. Microbiol., 59(11):3757-3752, 1993.

7. Okochi, M.; Nakamura, N.; Matsunaga, T. Electrochemical killing of microorganisms using the oxidized form of ferrocenemonocarboxylic acid. Electrochim. Acta, 44:3795-3799, 1999.

8. Patermarakis, G.; Fountoukidis, E. Disinfection of water by electrochemical treatment. Water Res., 24(12):1491-1496, 1990. 